\title{
Archaeological Testing at Two Well Locations in New Braunfels, Comal County, Texas
}

Daniel R. Potter

Follow this and additional works at: https://scholarworks.sfasu.edu/ita

Part of the American Material Culture Commons, Archaeological Anthropology Commons, Environmental Studies Commons, Other American Studies Commons, Other Arts and Humanities Commons, Other History of Art, Architecture, and Archaeology Commons, and the United States History Commons

Tell us how this article helped you.

This Article is brought to you for free and open access by the Center for Regional Heritage Research at SFA ScholarWorks. It has been accepted for inclusion in Index of Texas Archaeology: Open Access Gray Literature from the Lone Star State by an authorized editor of SFA ScholarWorks. For more information, please contact cdsscholarworks@sfasu.edu. 


\section{Archaeological Testing at Two Well Locations in New Braunfels, Comal County, Texas}

\section{Creative Commons License}

\section{(c) (1) (8)}

This work is licensed under a Creative Commons Attribution-NonCommercial 4.0 International License 
ARCHAEOLOGICAL TESTING AT TWO WELL LOCATIONS IN NEW BRAUNFELS, COMAL COUNTY, TEXAS

Daniel R. Potter

Center for Archaeological Research

The University of Texas at San Antonio

Archaeological Survey Report, No. 187 





\section{ARCHAEOLOGICAL TESTING AT TWO WELL LOCATIONS IN NEW BRAUNFELS, COMAL COUNTY, TEXAS}

Daniel R. Potter

Texas Antiquities Committee Permit No. 764

Jack D. Eaton, Principal Investigator

Center for Archaeological Research The University of Texas at San Antonio ${ }^{\circledR}$ Archaeological Survey Report, No. 187 
The following information is provided in accordance with General Rules of Practice and Procedure, Chapter 41.11 (Investigative Reports), Texas Antiquities Committee:

1. Type of investigation: archaeological testing of two proposed groundwater monitoring well localities;

2. Project name: Edwards Underground Water District Test Well Site;

3. County: Comal;

4. Principal investigator: Jack D. Eaton;

5. Name and location of sponsoring agency: Edwards Underground Water District, San Antonio, Texas;

6. Texas Antiquities Committee Permit No. 764;

7. Published by the Center for Archaeological Research, The University of Texas at San Antonio, San Antonio, Texas 78285-0658, 1989.

A list of publications offered by the Center for Archaeological Research can be obtained by sending $\$ 1.00$ to the Center for Archaeological Research, The University of Texas at San Antonio, San Antonio, Texas 78285-0658. 


\begin{abstract}
In March 1989, archaeologists from the Center for Archaeological Research, The University of Texas at San Antonio conducted a subsurface testing program at two localities proposed for well drilling by the Edwards Underground Water District in New Braunfels, Texas. The testing was done to locate and evaluate any archaeological remains which might be affected by well drilling. Prehistoric archaeological remains were encountered at Well Locality 1, but Well Locality 2 was devoid of any cultural materials. No significant damage to archaeological resources is expected with the drilling of the proposed wells. However, monitoring the drilling operation at Well Locality 1 is recommended if subsurface disturbance by heavy equipment is expected in the area of site 41 CM 25.
\end{abstract}


TABLE OF CONTENTS

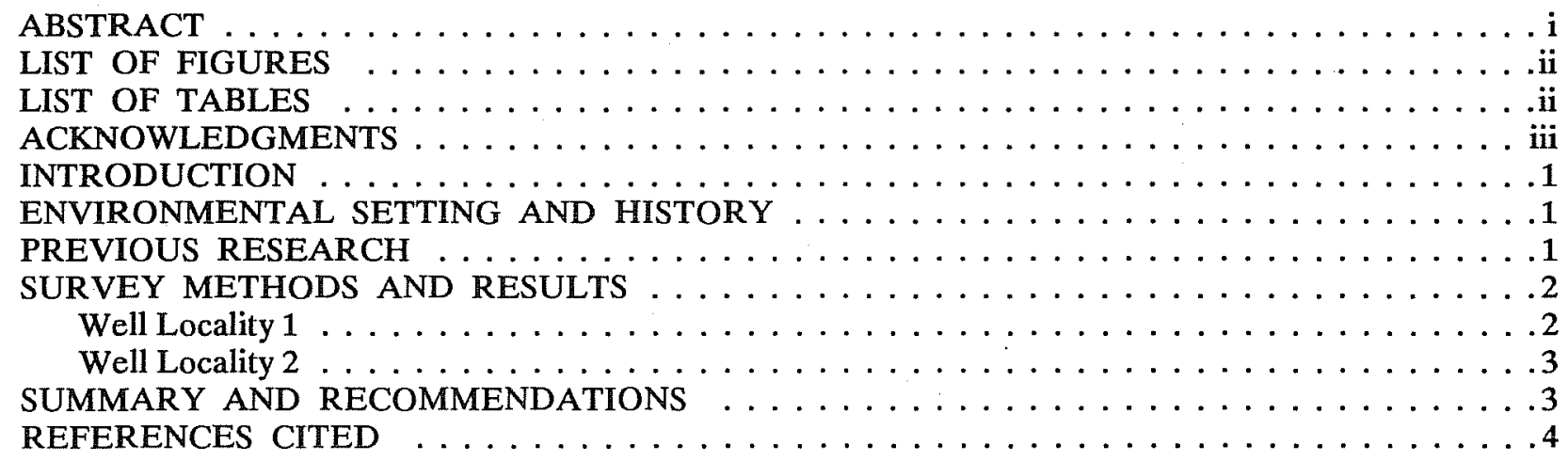

\section{LIST OF FIGURES}

1. Area of Edwards Underground Water District Test Well Locality $1 \ldots \ldots \ldots \ldots$

2. Area of Edwards Underground Water District Test Well Locality $2 \ldots \ldots \ldots$

\section{LIST OF TABLES}

1. Inventory of Excavated Materials from Well Locality $1 \ldots \ldots \ldots \ldots \ldots \ldots$ 


\section{ACKNOWLEDGMENTS}

The author wishes to thank several people for their kind assistance in completing the project. Mr. Robert Bader, senior geologist with the Edwards Underground Water District, and his assistant, John Hoyt, provided information and assistance to the project during field investigations. Mr. Mark Denton, staff archaeologist with the Texas Antiquities Committee, visited the site and provided valuable information concerning the archaeology and geomorphology of the immediate area. Greg Wood and my wife, Maureen Brown, made up the CAR-UTSA field crew for the project. Brown also did the drafting of the figures for this report. Gail L. Bailey, archaeologist with Prewitt and Associates, Inc., of Austin, Texas, provided additional unpublished and published information on the archaeology of site $41 \mathrm{CM} 25$ and the surrounding area. Jack D. Eaton, acting director of the Center for Archaeological Research, supervised this project. The office staff at the Center for Archaeological Research-Elizabeth Legge and Brenda Stevens-were instrumental in the preparation of this report. 



\section{INTRODUCTION}

In October 1988, Mr. Robert Bader of the Edwards Underground Water District (EUWD) requested that archaeological investigations be carried out by the Center for Archaeological Research (CAR) at The University of Texas at San Antonio (UTSA) in order to evaluate and report any archaeological resources which might be affected by the drilling of two groundwater monitoring wells in New Braunfels, Texas. The proposed location for the two wells was near or possibly within site $41 \mathrm{CM} 25$, an important prehistoric site which had received professional attention as early as 1936 (Bailey and Bousman 1989) with the discovery of numerous human burials.

Field investigations began March 21, 1989, and continued for three days. These investigations included a surface walkover, excavation of a $2-\mathrm{m}^{2}$ test unit, and shovel testing at Well Locality 1 . Additional work requested under this contract was for an archaeologist to monitor a backhoe trench located at Well Locality 2. The trench was excavated in order to evaluate the impact of proposed EUWD drilling in this area.

All field work was directed by Daniel Potter, and project supervision was provided by Jack D. Eaton, principal investigator and acting director of the CAR-UTSA. The work crew consisted of three archaeologists. Texas Antiquities Committee (TAC) Permit No. 764 was issued for this project. The field work followed the general recommendations outlined by the TAC (letter dated September 28, 1988, Mark Denton to Robert Bader). All field notes, photographs, and other information pertinent to this project are curated at the CAR-UTSA.

\section{ENVIRONMENTAL SETTING AND HISTORY}

The study area is located on an eroded secondary terrace on the west margin of the Comal River drainage. Soils in this setting are generally deep and include Pleistocene channel and overbank deposits left by the Comal River drainage system, and more recent Holocene clay loam surface soils (Bailey and Bousman 1989:21; Mark Denton, personal communication, 1989). Soil depth is variable and in places can be quite shallow.

Both investigated localities were covered with grass, with bordering oak trees, shrubs, and vines. North and east of the test localities, closer to the Comal River, walnut, pecan, and oak trees dominate. Well Locality 1 is the present location of a baseball field, and Well Locality 2 is an unused lot.

In the past, both localities have seen usage and modification. Well Locality 1 , including the area of archaeological site $41 \mathrm{CM} 25$, has been cultivated for various purposes since the late 19th century (Bailey and Bousman 1989:9). Major impacts in this area and particularly on this important site include Fredericksburg Road, which has probably bisected $41 \mathrm{CM} 25$, and the construction of a "Hi-Line" power transmission tower within the site, probably during the 1920s. Well Locality 2 has seen less disturbance, with only residential and railroad construction, both dating to the early 20th century, and neither producing noticeable subsurface damage.

\section{PREVIOUS RESEARCH}

The general study area has been the focus of archaeological research since the 1920 s, when local collectors encountered artifacts and human burials along Fredericksburg Road in the Landa Park area (Bailey, personal communication, 1989). By the 1930s, these activities gained the attention of Arthur Woolsey of The University of Texas at Austin and George Woodbury of Harvard University, Cambridge, Massachusetts. A cooperative project between the two institutions in 1936, directed by Woolsey and partially funded by Harvard, revealed 19 burials and associated artifacts occurring ca. $1.5 \mathrm{~m}$ below the surface. Diagnostic artifacts from the Middle Archaic period to the Late Prehistoric period occurred in the area of these interments (Bailey and Bousman 1989). Woolsey's excavation was apparently linear in shape and located immediately west of and parallel to Fredericksburg Road, south of Howard Street. His excavations occurred $50 \mathrm{~m}$ north-northeast of the testing at Well Locality 1.

As mentioned, local collectors have long been active in the Fredericksburg Road area, and Gail Bailey of Prewitt and Associates, Inc., Austin, Texas, has documented a number of diagnostic artifacts originating both from $41 \mathrm{CM} 25$ and from nearby areas along Fredricksburg Road (Bailey and Bousman 1989:12; Bailey, personal communication, 1989). Analysis of these collections shows that the area has seen constant human activity from Early Archaic times through the latter part of the Late Prehistoric period.

While several projects have focused on the archaeology of nearby Landa Park (Bailey and Bousman 1989), of more importance to the present study is a 1987 survey by Woody Wooldridge of an area immediately east of Well Locality 1. His investigations, which took place directly across Fredericksburg Road from the current study area, revealed surficial cultural materials and two subsurface cultural strata, the deepest of which occurred at $1.5 \mathrm{~m}$ below the surface (Bailey and Bousman 1989; Mark Denton, personal 
communication, 1989). This deeper stratum may correlate with Woolsey's burial component across Fredericksburg Road.

Although Well Locality 2 is within the general area of Well Locality 1 , it is not located within or near any recognized archaeological sites, and has not been the focus of previous archaeological study.

\section{SURVEY METHODS AND RESULTS}

The present study utilized a $100 \%$ surface examination, shovel testing, a $2-\mathrm{m}^{2}$ test unit, and a backhoe trench. All hand-excavated soil was screened.

\section{Well Locality 1}

Three subsurface excavations were completed at Well Locality 1 (Fig. 1). Unit 1 was a $2-\mathrm{m}^{2}$ excavation directly overlying the proposed EUWD drill hole 1 . Surprisingly, weathered limestone bedrock was encountered throughout Unit 1 at $30 \mathrm{~cm}$ below the surface. This was an unsuspected outcome, given the deep soils encountered by both the EUWD and archaeologists who had worked in the area previously.
Even with this very shallow soil deposit, moderate amounts of patinated chert debitage and a single exhausted core were encountered within Level 1 in this unit (see Table 1). Cultural materials were slightly more numerous in Level 2, with most materials lying within small erosional pockets of the limestone bedrock. This disposition of cultural materials, plus a marked degree of patination on much of the material, suggests a deflated depositional environment. Two biface fragments were recovered from this context in Level 2, a nondiagnostic thin biface distal fragment and an incomplete Early Archaic projectile point which roughly conforms to the Early Corner Notched or $U$ valde types.

In order to further evaluate soil depth and cultural resources at Well Locality 1 , two shovel tests were excavated to the north of Unit 1. Shovel Test 1 (ST 1) was located $15 \mathrm{~m}$ north-northwest of Unit 1 , and was excavated to a depth of $50 \mathrm{~cm}$. Nine chips, or flake fragments, were encountered within the test (Table 1), and a gradual change to lighter soil was noted at ca. 30 to $40 \mathrm{~cm}$ below the surface. Shovel Test 2 (ST 2) was located $30 \mathrm{~m}$ north of Unit 1 . It was also excavated to a depth of $50 \mathrm{~cm}$, but produced no lithics and a single minute ceramic fragment which may be of the Late Prehistoric Leon Plain type (Table 1). Our testing has demonstrated that as distance increases from EUWD

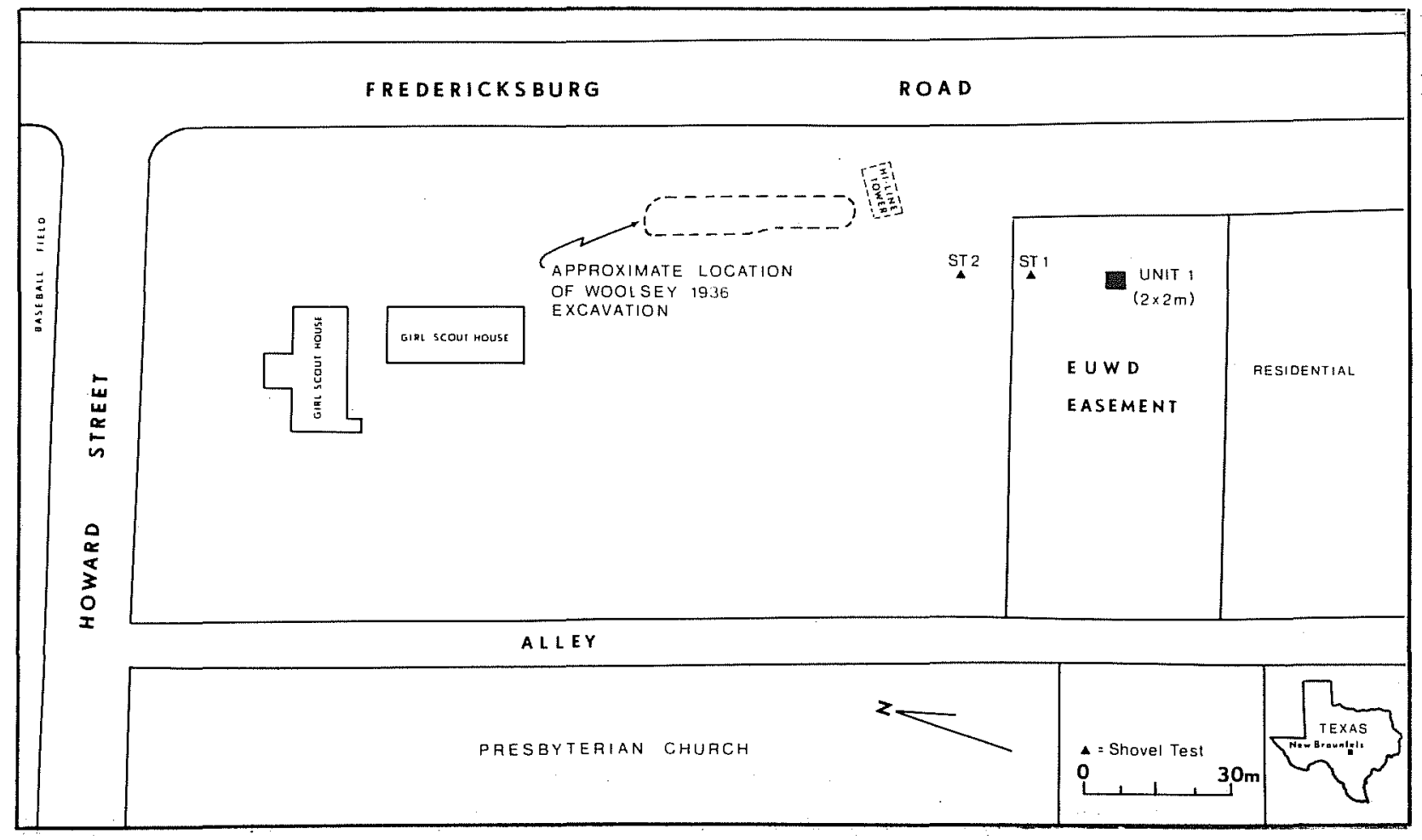

Figure 1. Area of Edwards Underground Water District Test Well Locality 1. Indicated are locations of Unit 1 and Shovel Tests 1 and 2. 
Well Locality 1 towards the north-northwest, soil depth increases markedly, as does the potential for buried archaeological materials. The specific locale, which will be impacted by EUWD test well drilling at Well Locality 1, possesses very shallow soil, and while cultural materials exist here, there is very little chance that drilling will adversely affect buried cultural remains such as those encountered by Woolsey in 1936.

TABLE 1. INVENTORY OF EXCAVATED MATERIALS FROM WELL LOCALITY 1

\begin{tabular}{|c|c|c|c|c|c|c|c|}
\hline 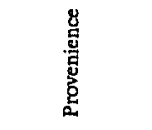 & 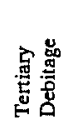 & 思 & 总 & 8 & $\begin{array}{l}\text { ष्: } \\
\text { : }\end{array}$ & $\begin{array}{l}\frac{Z}{g} \\
\text { 吾 }\end{array}$ & 嘿 \\
\hline Unit 1, Level 1 & 5 & 1 & 59 & 1 & & & 66 \\
\hline Unit 1, Level 2 & 13 & 3 & 88 & & 2 & & 106 \\
\hline Shovel Test 1 & & & 9 & & & & 9 \\
\hline Shovel Test 2 & & & & & & 1 & 1 \\
\hline Total & 18 & 4 & 156 & 1 & 2 & 1 & 182 \\
\hline
\end{tabular}

\section{Well Locality 2}

At EUWD Well Locality 2 (Fig. 2), a single backhoe trench was monitored, with only 20th-century construction materials being observed. The trench was excavated to a maximum depth of $2.10 \mathrm{~m}$. Recent historic building materials were encountered in the top $20-30 \mathrm{~cm}$ of the trench, and consisted of round nails and window glass. Below this topsoil zone, at 60 to $75 \mathrm{~cm}$ below the surface, the dark brown clay loam graded into light brown variegated soil with mixed Rabdotus and Helicina snail shells. With increasing depth, soil color became lighter and contained increasing amounts of carbonate inclusions. No buried cultural remains were observed, and no further investigations were initiated at Well Locality 2.

\section{SUMMARY AND RECOMMENDATIONS}

Because of the high archaeological value of site 41 CM 25, EUWD Well Locality 1 is a very sensitive area. The investigations at this locale demonstrated the existence of archaeological remains within the

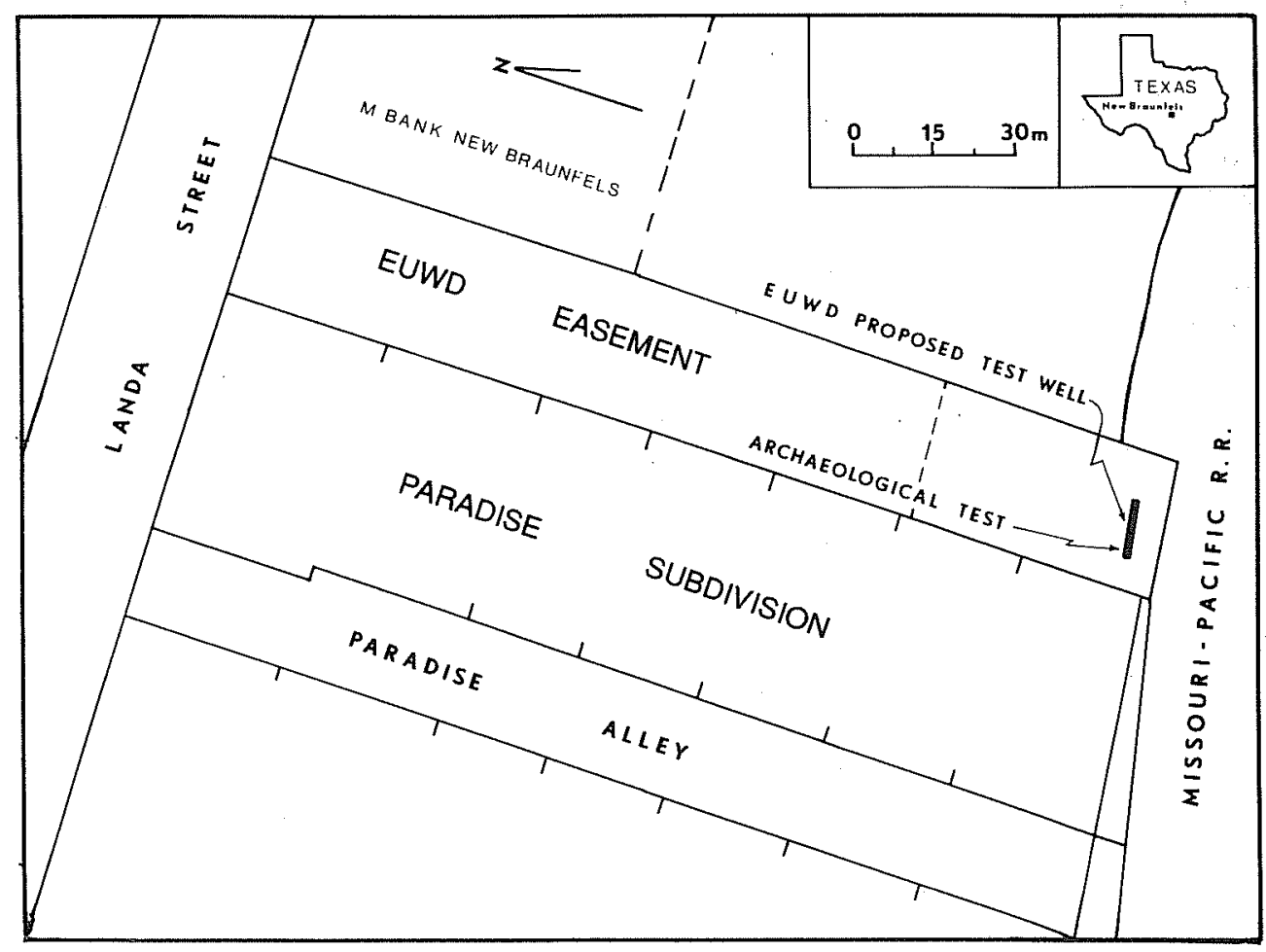

Figure 2. Area of Edwards Underground Water District Test Well Locality 2. Indicated is the archaeological test trench. 
drilling area. Furthermore, the recovery of a single diagnostic projectile point from Unit 1, Level 2, allows tentative dating of this cultural deposit to the Early Archaic period (6000-2500 B.C.). However, the vertical disposition of cultural materials within the very thin soil and the patination exhibited by these materials suggest that this portion of $41 \mathrm{CM} 25$ has experienced substantial postdepositional vertical movement through soil deflation. In addition, the shallow soil/bedrock situation at drilling Well Locality 1 negates the danger of disturbing deeply buried remains which are known to exist elsewhere at this site. Drilling at Well Locality 1 as currently planned will not significantly damage intact archaeological remains at 41 CM 25. However, it is recommended that all EUWD activities at Well Locality 1 involving any subsurface disturbance by heavy equipment be monitored by an archaeologist. In this way preservation of any remaining intact portions of the site will be ensured.

Because of a complete lack of cultural materials or other evidence of archaeological remains within the Well Locality 2 drilling area, no further archaeological investigations are necessary in association with the EUWD test well.

\section{REFERENCES CITED}

Bailey, G. L. and C. B. Bousman

1989 Subsurface Archaeological Survey and Monitoring of the Landa Street/ Fredericksburg Road Drainage Improvement Project, Comal County, Texas. Prewitt and Associates, Inc., Technical Reports 6. Austin. 



